\title{
ANALISIS EFFLUENT LIMBAH CAIR PT DNP INDONESIA. PULOGADUNG, JAKARTA TIMUR
}

\author{
Yuyun Kurniawati' ${ }^{1)}$, Naely Maqfiroh ${ }^{2)}$ \\ Progam Studi S1 Kesehatan Masyarakat Universitas MH. Thamrin \\ yunkurnia73@gmail.com
}

\begin{abstract}
ABSTRAK
Instalasi Pengolahan Air Limbah (IPAL/ WWTP (Waste Water Treatment Plant)) adalah sebuah struktur yang dirancang untuk membuang limbah biologis dan kimiawi dari air sehingga memungkinkan air tersebut untuk digunakan pada aktivitas yang lain. IPAL yang beroperasi dengan baik akan menghasilkan limbah cair keluaran (effluent) yang sesuai dengan standar baku mutu lingkungan. Penelitian bertujuan untuk menganalisa unsur yang terkandung di dalam effluent. Desain penelitian bersifat deskriptif analitik. Sampelnya adalah air limbah keluaran (effluent) yang diuji di Balai Besar Laboratorium Jakarta. Penelitian dilaksanakan bulan April-Juni 2017 bertempat PT DNP Indonesia. Hasil analisa menyatakan bahwa unsur $\mathrm{pH}$, suhu, COD, unsur Kromium Total, dan Kromium Valensi 6 yang masih memenuhi standart baku mutu lingkungan sesuai dengan PERGUB DKI No. 69 Tahun 2013. Air limbah aman dibuang ke badan air. Perlunya perusahaan untuk selalu mengawasi Kinerja IPAL pada setiap unit prosesnya agar air limbah aman dialirkan ke badan air, dan pentingnya pemeriksaan secara rutin air limbah keluaran (effluent) sebagai bentuk peduli lingkungan.
\end{abstract}

Kata Kunci: Analisis, Effluent, IPAL

\section{PENDAHULUAN}

Salah satu penyebab terjadinya pencemaran air adalah air limbah yang dibuang tanpa pengolahan kedalam suatu badan air. Tingkat pencemaran baik kualitas maupun kuantitas semakin meningkat, akibat perkembangan penduduk dan ekonomi, termasuk industri di sepanjang sungai yang tidak melakukan pengelolaan air limbah industrinya secara optimal. ${ }^{2}$

Pencemaran air limbah bisa dikatakan sebagai salah satu dampak pembangunan di berbagai bidang disamping memberikan manfaat bagi kesejahteraan rakyat. Selain itu peningkatan pencemaran lingkungan juga diakibatkan dari meningkatnya jumlah penduduk beserta aktifitasnya. Limbah yang berbentuk cair yang tidak dikelola dengan baik bisa menimbulkan bahaya terhadap lingkungan dan kesehatan manusia serta makhluk hidup lainnnya. $^{7}$

Upaya pencegahan timbulnya pencemaran lingkungan dan bahaya yang diakibatkannya serta yang akan menyebabkan kerugian sosial ekonomi, kesehatan dan lingkungan, maka harus ada pengelolaan secara khusus terhadap limbah tersebut agar bisa dihilangkan atau dikurangi sifat bahayanya. Selain itu, perlu diusahakan metode pengelolaan yang ramah lingkungan serta pengawasan yang benar dan cermat oleh berbagai pihak. ${ }^{8}$

Seiring dengan makin tingginya kepedulian akan kelestarian sungai dan kepentingan berkelanjutan lingkungan dan dunia usaha akan muncul upaya industri untuk melakukan pengelolaan air limbah industrinya melalui perencanaan proses produksi yang efisien sehingga mampu meminimalkan limbah buangan industri dan upaya pengendalian pencemaran air limbah industrinya melalui penerapan instalasi pengelolaan air limbah. ${ }^{10}$

Pengendalian/penanggulangan pen-cemaran air di Indonesia telah diatur melalui peraturan pemerintah Nomor 32 tahun 2001 tentang pengelolaan Kualitas dan pengendalian Pencemar Air. Secara umum hal ini meliputi pencemaran air baik oleh instansi ataupun noninstansi. ${ }^{2}$

PT DNP Indonesia merupakan salah satu perusahaan industri manufaktur yang telah memiliki Instalasi Pengelolaan Air Limbah. Dalam rangka mendukung program pembangunan berwawasan dan berkelanjutan, 
maka perlu dilakukan upaya peningkatan-peningkatan efektifitas dan efisiensi pengolahan. Selain itu, sejalan dengan kegiatan produksi PT DNP Indonesia yang setiap harinya memproduksi berbagai produk kemasan baik makanan, kosmetik dan masih banyak lagi produk kemasan lainya, jelas perusahaan ini pastinya menghasilkan banyak sekali limbah khususnya limbah cair yang jika di buang secara langsung melalui saluran pembuangan air tanpa diolah terlebih dahulu, tentunya akan mencemari lingkungan dan membahayakan masyarakat khususnya yang tinggal di sekitar kawasan dekat perusahaan.

Sehubungan dengan hal tersebut, perlunya mengetahui nilai kandungan unsur-unsur yang ada di dalam air limbah tersebut dengan melakukan uji laboratorium. Hal ini dilakukan dalam upaya mencegah terjadinya pencemaran air yang serius yang dapat mengancam kelangsungan hidup di masyarakat sekitar.

PT DNP Indonesia sudah memiliki Instalasi Pengolahan Air limbah, dengan metode WWTP (konversi dari polutan- polutan yang tersuspensi koloid yang sangat halus di dalam air limbah, menjadi gumpalan-gumpalan yang dapat diendapkan, disaring, atau diapungkan Koagulasi bertujuan untuk membuat gumpalan yang lebih besar dengan penambahan bahan kimia). Diketahui data sekunder hasil laboratorium kualitas Air Limbah yang didapat 2 tahun terakhir didapatkan hasil kualitas Air limbah WWTP Elektroplating seperti Ph, COD, Kromium Total dan Tembaga terlihat masih ada parameter yang melebihi baku mutu yang dianjurkan seperti pH dan COD yaitu pada tahun 2017 nilai pH 9 yang seharusnya 7 dan nilai COD 77 mg/l yang seharusnya $75 \mathrm{mg} / \mathrm{l}$.

\section{BAHAN DAN METODE}

Jenis penelitian ini adalah jenis penelitian deskriptif analitik. Penelitian ini lebih mengarah pada hasil laboratorium kualitas air limbah WWTP Elektroplating di Instalasi Pengelolaan Air Limbah di PT DNP Indonesia.

Penelitan ini akan di dilakukan di Instalasi Pengelolaan Air Limbah di PT. DNP Indonesia, Pulogadung, Jakarta Timur Tahun 2018. Sampel dalam penelitian ini adalah air limbah keluaran (Effluent) tanggal 18 juli 2018 pukul 06.00 dan tanggal 19 Juli 2018 pukul 13.00.

\section{HASIL}

Data sekunder dari PT. DNP Indonesia tahun 2017 mengenai debit air limbah yang dihasilkan setiap harinya pada unit GCM rata-rata sebanyak 4,5 m³/hari, debit air ini terakumulasikan dari air limbah yang di hasilkan selama tiga shift pengoperasianpada pada IPAL Tabel 1.

Tabel 1.

Data Inlet/ inffluent IPAL PT DNP Indonesia Tahun 2017

\begin{tabular}{|c|c|c|}
\hline Jenis Shift & Waktu & Jumlah / m³ \\
\hline Pagi & $07.00-15.00$ & 1,5 \\
\hline Siang & $15.00-23.00$ & 1,5 \\
\hline Malam & $23.00-07.00$ & 1,5 \\
\hline \multicolumn{2}{|c|}{ Total } & 4,5 \\
\hline
\end{tabular}

Sumber : Laporan Data Inlet Air limbah Unit GCM

Semua air limbah tersebut masuk ke dalam Bak inffluent (raw waste tank) yang ada di dalam tanah, kemudain dialirkan ke unit IPAL untuk dilakukan proses selanjutnya. Air limbah di olah selama 2-3 kali proses di dalam 
unit IPAL, selanjutnya air limbah yang telah melalui pengolahan tersebut dibuang ke badan air. Jumlah debit outlet/effluent hasil olahan IPAL PT DNP Indonesia menghasilkan sebanyak 4 m³/hari pada Tabel 2.

Tabel 2.

Data Outlet/ Effluent IPAL PT DNP Indonesia Tahun 2017

\begin{tabular}{|c|c|c|}
\hline Pembuangan & Waktu & Jumlah/ $\mathbf{m}^{3}$ \\
\hline Pagi & $07.00-08.00$ & 2,3 \\
\hline Siang & $13.00-15.00$ & 1,7 \\
\hline \multicolumn{2}{|c|}{ Total } & 4 \\
\hline
\end{tabular}

Sumber : Laporan Data Effluen Air limbah Unit GCM, 2017

Sementara air limbah yang akan dibuang ke badan air, terus dilakukan pengujian di laboratorium. Data Hasil pengujian Laboratorim Kualitas Air Limbah effluent WWTP Elektroplating PT DNP Indonesia Tahun 2016-2018 menunjukkan nilai parameter pH, Temperatur Suhu, COD, Kromium Total dan Kromium Valensi 6 yang masih memenuhi Baku mutu menurut PERGUB DKI Jakarta No. 69 Tahun 2013 tentang Baku mutu Industri Pelapisan Logam pada Tabel 3.

Tabel 3.

Data Hasil Pengujian Laboratorim Kualitas Air Limbah Effluent WWTP Elektroplating PT DNP Indonesia Tahun 2016-2018

\begin{tabular}{|c|c|c|c|c|c|c|}
\hline \multirow[t]{2}{*}{ No } & \multirow[t]{2}{*}{ Jenis Pengujian } & \multicolumn{3}{|c|}{$\begin{array}{c}\text { Hasil rata- rata } \\
\text { pengujian } \\
\text { (per Tahun) }\end{array}$} & \multirow{2}{*}{$\begin{array}{c}\text { Bak } \\
\mathbf{u} \\
\mathbf{M u t} \\
\mathbf{u}\end{array}$} & \multirow[t]{2}{*}{ Ket } \\
\hline & & 2016 & 2017 & 2018 & & \\
\hline 1 & $\mathrm{pH}$ & 7,2 & 7 & 7 & $6-9$ & $\begin{array}{l}\text { - Memenuhi baku } \\
\text { mutu }\end{array}$ \\
\hline 2 & Temperatur Suhu & 25 & 26 & 26 & $\begin{array}{l}30 \\
{ }^{3} \mathrm{C}\end{array}$ & $\begin{array}{l}\text { - Memenuhi baku } \\
\text { mutu }\end{array}$ \\
\hline 3 & COD & 44 & 50 & 47 & $\begin{array}{c}75 \\
\mathrm{mg} / \mathrm{l}\end{array}$ & $\begin{array}{c}\text { - Memenuhi baku } \\
\text { mutu }\end{array}$ \\
\hline 4 & Kromium Total & 0,03 & 0,03 & 0,01 & $\begin{array}{c}1 \\
\mathrm{mg} / \mathrm{l}\end{array}$ & $\begin{array}{l}\text { - Memenuhi baku } \\
\text { mutu }\end{array}$ \\
\hline 5 & Kromium Valensi 6 & $\begin{array}{c}<0,0 \\
4\end{array}$ & $\begin{array}{c}<0,0 \\
1\end{array}$ & $\begin{array}{c}< \\
0,01\end{array}$ & $\begin{array}{c}1 \\
\mathrm{mg} / \mathrm{l}\end{array}$ & $\begin{array}{c}\text { - Memenuhi baku } \\
\text { mutu }\end{array}$ \\
\hline
\end{tabular}

Sumber: Laporan Hasil pengujian Laboratorim Kualitas Air Limbah WWTP Elektroplating PT DNP Indonesia Tahun 2016-2018

Data kualitas effluent perbulan dikumpulkan dan d irata-rata. Penghitungan hasil pada tabel 3 tersebut berdasarkan nilai rata-rata pertahun yang dikumpulkan PT DNP Indonesia setiap bulannya.

Selain data sekunder, dilakukan juga pengambilan sampel air limbah effluent secara primer dan diuji kualitas Air Limbah PT DNP Indonesia tersebut oleh Balai Besar Laboratorium Jakarta. Dan hasilnya di analisa sesuai dengan standart baku mutu kualitas limbah PERGUB Provinsi DKI Jakarta No. 69 Tahun 2013 tentang baku mutu air limbah Industri Pelapisan Logam. Berdasarkan hasil pengujian sampel air di laboratorium khususnya parameter Fisika pH, Suhu, parameter kimia COD, Kromium Total, dan Kromium Valensi 6 diperolah hasil telah memenuhi baku mutu dan syarat kesehatan yang ditentukan pada Tabel 4. 
Tabel 4.

Hasil pengujian Laboratorim Sampel Air Limbah Effluent WWTP Elektroplating PT DNP Indonesia Tahun 2018

\begin{tabular}{|c|c|c|c|c|c|}
\hline \multirow[b]{2}{*}{ No } & \multirow[b]{2}{*}{$\begin{array}{c}\text { Jenis } \\
\text { Pengujian }\end{array}$} & \multicolumn{2}{|c|}{ Hasil Pengujian } & \multirow[b]{2}{*}{$\begin{array}{l}\text { Baku } \\
\text { Mutu }\end{array}$} & \multirow[b]{2}{*}{ Ket. } \\
\hline & & $\begin{array}{c}\text { Sampel I } \\
\text { 18 Juli } 2018 \\
\text { Pagi }\end{array}$ & $\begin{array}{c}\text { Sampel II } \\
\text { 19 Juli } 2018 \\
\text { Siang }\end{array}$ & & \\
\hline 1 & $\mathrm{pH}$ & 7,37 & 6,08 & $6-9$ & - Memenuhi baku mutu \\
\hline 2 & $\begin{array}{l}\text { Temperatur } \\
\text { Suhu }\end{array}$ & 23,1 & 25,5 & $30^{0} \mathrm{C}$ & - Memenuhi baku mutu \\
\hline 3 & COD & 9,8 & 27,2 & $75 \mathrm{mg} / \mathrm{l}$ & - Memenuhi baku mutu \\
\hline 4 & $\begin{array}{l}\text { Kromium } \\
\text { Total }\end{array}$ & 0,008 & $<0,002$ & $1 \mathrm{mg} / \mathrm{l}$ & - Memenuhi baku mutu \\
\hline 5 & $\begin{array}{l}\text { Kromium } \\
\text { Valensi } 6\end{array}$ & $<0,009$ & $<0,009$ & $1 \mathrm{mg} / \mathrm{l}$ & - Memenuhi baku mutu \\
\hline
\end{tabular}

Sumber : Laporan pengujian sampel Air limbah WWTP Elektroplating Balai besar

laboratorium Kesehatan Jakarta tahun 2018

Hasil Effluent air limbah WWTP Elektroplating PT DNP Indonesia didapatkan bahwa semua parameter yang telah diuji tidak ada yang melebihi baku mutu yang dianjurkan sehingga aman untuk di buang di badan air. Dari hasil 2 kali pengujian laboratorium yang dilakukan peneliti juga di dapatkan adanya penurunan kandungan dari parameter-parameter yang diuji. Ini menunjukkan bahwa sistem pengolahan air limbah PT DNP Indonesia dalam keadaan beroperasi dengan baik.

\section{PEMBAHASAN}

Seluruh air limbah yang diolah pada IPAL merupakan air limbah yang dihasilkan dari kegiatan pelapisan logam krom (limbah WWTP electroplating) yang berasal dari unit GCM (Gravure Maxing Cylinder). karakteristik limbah yang dihasilkan adalah air limbah yang beracun. Dengan karakteristik tersebut, maka perlu untuk diketahui karakteristik fisik, dan kimia dari air limbah untuk mengetahui ukuran kandungan kimia berbahaya air limbah yang nantinya akan dibuang ke badan air yang disesuaikan dengan baku mutu. ${ }^{5}$ Beberapa unsur logam yang terdapat dalam limbah cair elektroplating antara lain besi, krom, seng, mangan, dan tembaga. Tingkat toksisitas yang sangat berbahaya adalah pada unsur krom, nikel dan seng Berdasarkan data sekunder dari pihak petugas pengelola IPAL PT DNP Indonesia, pengecekan kualitas air limbah dilakukan setiap satu bulan sekali oleh pihak UNILAB, diketahui bahwa karakteristik effluent air limbah yang adalah $\mathrm{pH}$, TSS, Kadmium, Sianida, Kromium Total, Kromium Valensi 6, seng, tembaga, nikel, COD, Timbal, dan perak. Hasil pemeriksaan tersebut dilaporkan kembali ke pihak pengelola IPAL. Dalam pelaksanaanya, pengecekkan effluent air limbah yang dilakukan setiap satu bulan sekali ini juga sebagai kontrol besaran kadar atau kandungan unsur sebelum dibuang ke badan air dan disesuaikan dengan baku mutu yang telah ditetapkan yaitu PERGUB Provinsi DKI Jakarta No. 69 Tahun 2013 tentang baku mutu air limbah industri pelapisan logam terutama pada nilai pH, COD, Kromium Total dan Kromium Heksavalens. ${ }^{15}$

\section{Analisa Effluent PT DNP Indonesia Berdasarkan Standar Baku Mutu}

Selanjutkan akan dilakukan Analisa effluent berdasarkan dua hasil laboratorium pengujian air limbah WWT Elektroplating untuk parameter pH, COD, Kromium Total dan Kromium Valensi 6 yang penulis lakukan di 
BBLKJ (Balai Besar Laboratorium Kesehatan Jakarta) disesuaikan dengan baku mutu Air Limbah yang di tetapkan pada PERGUB Provinsi DKI Jakarta No. 69 Tahun 2013. ${ }^{15}$

\section{pH (derajat keasaman)}

Dalam hasil uji laboratorium 2 sampel air di waktu yang berbeda yaitu pagi dan sore dihasilkan bahwa nilai PH pada effluent IPAL PT DNP Indonesia berada pada batas yang aman untuk dibuang ke badan air. Berdasarkan baku mutu lingkungan yang ditetapkan oleh PERGUB Provinsi DKI Jakarta No. 69 Tahun 2013 tentang Limbah Pelapisan Logam, dinyatakan bahwa derajat keasaman air limbah yang aman dibuang ke badan air penerima adalah yang berada dalam rentang $\mathrm{pH}$ 6-9.

Angka baku mutu pada rentang untuk derajat keasaman ini karena pada rentang tersebut air berada pada kondisi netral, tidak terlalu asam dan tidak terlalu basa. Jika kondisi air limbah yang telah diolah IPAL masuk ke badan air terlalu asam maka dapat menganggu stabilitas ekosistem di badan air tersebut. Sedangkan jika air yang masuk ke badan penerima terlalu basa, maka badan air tersebut akan mengandung kesadahan tinggi dan hal ini juga akan menganggu kualitas badan air penerima. ${ }^{10}$

Berdasarkan data hasil pemeriksaan kulaitas air limbah pada effluent IPAL terlihat bahwa derajat keasaman air limbah berada pada kondisi normal yaitu pada rentang 7,37 - 6,8. Ini menunjukkan bahwa kondisi kualitas air limbah effluen yang dihasilkan oleh PT DNP Indonesia masih dalam kondisi netral yang aman untuk dibuang ke badan air penerima karena tidak menganggu stabilitas ekosistem di badan air.

\section{Temperatur Suhu}

Suhu Air Limbah biasanya $\pm 3^{0} \mathrm{C}$ dari suhu udara atau $30^{\circ} \mathrm{C}$ ini menurut PERGUB Provinsi No. 69 Tahun 2013 Tentang Baku Mutu Air Limbah Pelapisan Logam. Temperatur air limbah mempengaruhi badan penerima bila terdapat perbedaan suhu yang cukup besar. Temperatur air limbah akan mempengaruhi kecepatan reaksi kimia serta tata kehidupan dalam air. ${ }^{24,25}$

Dapat dilihat dari hasil uji laboratorium yang dilakukan dari 2 kali pengujian sampel air limbah effluent diperoleh rentan suhu air limbah adalah $23,7-25^{\circ} \mathrm{C}$. Ini menunjukkan bahwa temperatur suhu pada effluent air limbah secara umum dapat dikatakan memenuhi baku mutu yang disyaratkan, nilai ini jauh lebih rendah dibanding dari baku mutu yang diperbolehkan sebesar $\pm 3{ }^{\circ} \mathrm{C}$ dari suhu udara atau $30^{\circ} \mathrm{C}$.

Tinggi rendahnya suhu air dipengaruhi oleh suhu udara disekitar dan intensitas paparan sinar matahari yang masuk ke badan air, intensitas sinar matahari dipengaruhi oleh awan, musim dan waktu dalam hari, semakin banyak intensitas sinar matahari yang mengnai badan air, maka akan membuat suhu air emakin tinggi. ${ }^{19,20}$ Dari hasil pengujian air limbah effluent di PT DNP Indonesia menunjukkan bahwa air limbah aman untuk dibuang di badan air karena tidak akan mempengaruhi tatanan hidup dalam air.

\section{COD (Chemical Oxygen Demand)}

Dalam hasil uji laboratorium 2 sampel air di waktu yang berbeda yaitu pagi dan sore dihasilkan bahwa nilai COD pada effluent IPAL PT DNP Indonesia berada pada batas yang aman untuk dibuang ke badan air. 
Konsentrasi COD pada effluent air limbah secara umum dapat dikatakan memenuhi baku mutu yang disyaratkan. Dengan rentang 9 - $28 \mathrm{mg} / \mathrm{l}$, nilai ini jauh lebih rendah dibanding dari baku mutu yang diperbolehkan sebesar $75 \mathrm{mg} / \mathrm{l}$.

Jika dilihat dari efisiensi penurunan kadar pencemar COD dapat disimpulkan proses pengolahan yang terjadi cukup berjalan dengan baik. Pada pengukuran COD, penurunan nilai (konsentrasi) COD ini dipengaruhi oleh penambahan koagulan/nutrien menjadi lebih sederhana, serta mampu mengoksidasi senyawa organik dan anorganik sehingga mengendap di dasar tangki. ${ }^{18}$ Dibuat serendah mungkin konsentrasi COD yang diharapkan.

Secara umum konsentrasi COD yang tinggi dalam air menunjukkan bahwa adanya bahan pencemar organik yang banyak. Sejalan dengan hal ini jumlah mikroorganisme, baik yang merupakan pathogen maupun tidak pathogen juga banyak. Adapun mikroorganisme pathogen dapat menimbulkan dapat menimbulkan berbagai macam penyakit bagi manusia. ${ }^{10}$

Selain itu konsentrasi COD yang tinggi menyebabkan kandungan oksigen-oksigen terlarut dalam air menjadi rendah bahkan habis sama sekali. Akibatnya oksigen sebagai sumber kehidupan bagi mahluk hidup di air tidak terpenuhi sehingga mahluk hidup tersebut menjadi mati. ${ }^{24}$

Sehingga dengan hasil COD yang telah rendah yaitu di bawah baku mutu lingkungan yang ditetapkan, maka disimpulkan air limbah dapat dibuang secara aman di badan air karena kadar COD yang terkandung dalam air tidak membahayakan bagi lingkungan baik bagi manusia maupun hewan dan tumbuhan yang hidup di badan air penerima.

\section{Kromium Total}

Konsentrasi Kromium Total pada effluent air limbah secara umum dapat dikatakan memenuhi baku mutu yang disyaratkan dengan rentang 0,002-0,088 mg/l. Nilai ini jauh lebih rendah dibanding dari baku mutu yang diperbolehkan diperbolehkan sebesar $1 \mathrm{mg} / \mathrm{l}$.

Menurut penelitian yang sebelumya telah dilakukan oleh Nurhasni et al, tahun 2013 yang berjudul "Pengolahan Limbah Industri Elektroplating Dengan Proses Koagulasi dan Flokulasi”, terjadinya penurunan kadar krom dikarenakan bahwa massa koagulan yang semakin banyak maka endapan $\mathrm{Cr}(\mathrm{OH}) 3$ semakin mudah terbentuk dan kadar logam $\mathrm{Cr}$ semakin menurun. Krom pada limbah akan berinteraksi dengan ion $\mathrm{OH}$ - yang menyebabkan $\mathrm{Cr}$ akan mengendap dalam limbah membentuk $\mathrm{Cr}(\mathrm{OH})_{3}$. Endapan $\mathrm{Cr}(\mathrm{OH})_{3}$ dapat berperan sebagai inti flok yang bersifat elektropositif dan akan menarik kelebihan $\mathrm{OH}$ - didalam larutan sehingga membentuk flok $\mathrm{Cr}(\mathrm{OH})^{4-}$ dan dapat menarik kation logam lainnya yang terdapat dalam limbah, dengan kata lain proses pengolahan air limbah dalam keadaan baik.

Bahaya krom sendiri apabila masuk ke dalam air dengan kondisi yang melebihi baku mutu yang diperbolehkan maka akan menimbulkan penyakit bagi manusia yang tidak sengaja mengkonsumsi air dengan kandungan krom yang tinggi. Logam $\mathrm{Cr}$ (Krom) yang masuk kedalam tubuh manusia akan berinteraksi dengan unsur-unsur biologis tubuh, dapat menyebabkan terganggunya fungsi-fungsi tertentu yang bekerja dalam proses metabolisme tubuh. Mencerna baik makanan ataupun minuman yang mengandung krom melebihi kadar normal tubuh (0,05 $\mathrm{mg} / \mathrm{kg}$ berat badan) bisa menyebabkan gangguan pencernaan, berupa sakit lambung, muntah, dan perdarahan, luka pada lambung, konvulsi, kerusakan ginjal dan hepar bahkan dapat meyebabkan kematian. ${ }^{24}$ 
Oleh karena itu dengan hasil uji laboratorium kualitas air limbah yang dihasilkan, bahwa kondisi air limbah di PT DNP Indonesia dapat dibuang secara aman di badan air, karena kandungan krom yang ada di dalam air limbah tidak melebihi baku mutu yang disyaratkan sehingga tidak akan mengganggu kesehatan masyarakat sekitar dan juga pencemaran lingkungan.

\section{Kromium Valensi 6}

Konsentrasi Kromium Valensi 6 pada effluent air limbah secara umum dapat dikatakan memenuhi baku mutu yang disyaratkan. Dengan hasil keduanya pengujian semuanya menunjukkan angkan $<0,009 \mathrm{mg} / \mathrm{l}$, nilai ini jauh lebih rendah dibanding dari baku mutu yang diperbolehkan sebesar $1 \mathrm{mg} / \mathrm{l}$.

Jika dilihat dari efisiensi penurunan kadar pencemar Kromium Valensi dapat disimpulkan proses pengolahan yang terjadi cukup berjalan dengan baik sehingga kandungan pencemar yang terkandung dalam air tidak melebihi baku mutu lingkungan, dengan turunya kadar kromium valensi 6 pencemaran lingkungan tidak akan terjadi, karena kandungan kromium valensi 6 besifat sangat toksik. Kandungan kromium valensi 6 yang tinggi dalam air apabila di konsumsi akan mempengaruhi proses metabolisme tubuh, zat atau senyawa ini akan menghalangi atau menghambat kerja enzim benzopiren hidroksilase. Penghambatan kerja enzim tersebut akan memicu tumbuhnya sel-sel kanker. ${ }^{14}$

Oleh karena itu dengan hasil uji laboratorium kualitas air limbah yang dihasilkan, bahwa kondisi air limbah di PT DNP Indonesia dapat dibuang secara aman di badan air, karena kandungan krom yang ada di dalam air limbah tidak melebihi baku mutu yang disyaratkan sehingga tidak akan mengganggu kesehatan masyarakat sekitar dan juga pencemaran lingkungan.

\section{Sistem IPAL}

Sistem IPAL di PT DNP Indonesia ini beroperasi dengan cukup baik dimana ada 3 bagian pengolahan terpenting untuk dapat mengolah air buangan supaya aman dibuang ke badan air yaitu :

a. Primary Treatment

Tujuan pengolahan di tahap primary treatment ini adalah menetralkan $\mathrm{pH}$ dengan menambahkan costic soda dan asam sulfat ke dalam air limbah dan untuk mempermudah proses pengendapan di secondary treatment dengan penambahan koagulan.

b. Secondary Treatment

Tujuan pengolahan pada tahap secondary treatment ini adalah untuk mengurangi kadar krom dan Flour dengan penambahan polymer, sodium, dan caustic soda $(\mathrm{NaOH})$, untuk menyaring air yang terkandung dalam sludge sehingga menghasilkan cake yang akan dibuang ke area disposal, serta untuk mengetahui padatan tersuspensi (Total Suspended Solid).

c. Unit Advanced Treatment

Di dalam pengolahan lanjutan (Advanced Treatment) ada 3 tahapan, yaitu sebagai berikut: Netralizer, Equalizer, Point L. 


\section{KESIMPULAN DAN REKOMENDASI}

Berdasarkan hasil penelitian dan pembahasan yang telah dilakukan maka dapat disimpulkan sebagai berikut :

1. Analisis untuk setiap parameter yang di uji di Balai Besar Laboratorium Kesehatan Jakarta berdasarkan PERGUB Povinsi DKI Jakarta No. 69 Tahun 2013 tentang Baku mutu air limbah Industri Pelapisan Logam yaitu Ph, Suhu, COD. unsur Kromium Total dan Krom Valensi 6 semuanya memenuhi baku mutu air limbah industri pelapisan logam yang ditetapkan sehingga aman untuk di buang ke badan air.

2. Sistem IPAL PT DNP Indonesia yang beroperasi sudah sesuai dengan SOP pengoperasiannya dan dibuktikan dengan uji kualitas air limbah effluent yang tidak melebihi baku mutu atau sudah sesuai standart.

Berdasarkan hasil penelitian yang dilakukan, saran yang dapat kami berikan adalah sebagai berikut :

1. Disarankan bagi pihak perusahaan untuk selalu melakukan monitoring Kinerja IPAL pada setiap prosesnya untuk menjaga kualitas air limbah aman di alirkan ke badan air.

2. Mengontrol dosis larutan Asam sulfat, Soda Kostik (NAHO) atau Natrium Karbonat (Na2CO2) untuk menetralkan kandungan $\mathrm{Ph}$ air limbah.

3. Pemeriksaan rutin air limbah perlu dilakukan agar mengetahui secara terus menerus kualitas air limbah effluent yang aman dan ramah kepada lingkungan, sebagai bentuk peduli lingkungan.

4. Penyiapan berkas laporan dan tata unit IPAL yang lengkap sehingga apabila ada kerusakan unit IPAL bisa segera diperbaiki dengan cepat.

\section{UCAPAN TERIMA KASIH}

Peneliti mengucapkan terima kasih kepada pihak-pihak yang telah banyak membantu dan dukungan dalam penyusunan penelitian. Ucapan terima kasih diucapkan kepada:

1. Direksi dan Manajemen PT DNP Indonesia

2. Petugas IPAL PT DNP Indonesia

3. Rektor Universitas MH Thamrin, Ketua Prodi Kesehatan Masyarakat Fakultas Kesehatan Masyarakat Universitas MH Thamrin beserta staf

\section{REFERENSI}

1. Anonim. Water Enviroment Management in Japan. Water Enviroment Departement Enviromental Management Bureau, Ministry of the Enviroment; 2001.

2. Arif, Sumantri. Kesehatan Lingkungan. Kencana: Jakarta; 2010.

3. Arief, L.M. Pengolahan Limbah Industri Dasar-dasar Pengetahuan dan Aplikasi di Tempat Kerja. Yogyakarta : CV Andi Offset; 2016.

4. Arikunto. Prosedur Penelitian Suatu Pendekatan Praktis. Jakarta: PT. Rineka Cipta; 2006.

5. Ginting P. Sistem Pengolahan Lingkungan Dan Limbah Industri. Bandung : Yrama Widya; 2007.

6. Grady Jr dkk. Bioligical Wastewater Treatment, Theory And Application.Marcel Dekker, Inc : New York and Basel; 1980.

7. Hamid, I. Sumber Energi dan Pencemaran Lingkungan. Bandung: PT Remaja Rosdakarya; 2010. 
8. Kemenkes, RI. Pedoman Teknis Instalasi Pengolahan Air Limbah Dengan Sistem Biofilter Anaerob Aerob Pada Fasilitas Pelayanan Kesehatan. Jakarta; 2011.

9. Metcal and Eddy. Water Engineering Treatment Disposial and Reuse, 3rd Eddition. Singapore : Mc Graw-Hill Book Co.; 2004.

10. Mukono HJ. Toksikologi Lingkungan. Surabaya : Airlangga Universty Press; 2010.

11. Nazir. Metode Penelitian. Jakarta: Ghalia Indonesia; 2005.

12. Nurhasni dkk, 2013. Pengolahan Limbah Industri Kecil Pelapisan Logam. www.jurnalnasionallingkungan. Diakses tanggal 28 Juli 2018.

13. Notoatmodjo, S. Metodologi Penelitian Kesehatan. Jakarta: PT Rineka Cipta; 2010.

14. Palar H. Pencemaran Dan Toksikologi Logam Berat. Jakarta : PT Rineka Cipta; 2004.

15. Pergub DKI Jakarta No. 69 Tahun 2013. Baku Mutu Air Limbah Industri Pelapisan Logam

16. PP RI No. 82 Tahun 2001. Pengelolaan Kualitas Air dan Pengendalian Pencemaran Air.

17. Prawasti pdk. Optimasi Pengunnaan Koagulan Pada Pengolahan Air Limbah Batubara. Prosiding Seminar Nasional Teknik Kimia "Kejuangan” Pengembangan Teknologi Kimia Untuk Pengelolahan Sumber Daya Alam Indonnesia. Jakarta : Universitas Indonesia; 2010.

18. Purwanto dkk. Teknologi Industri Elektroplating. Semarang : Universitas Diponegoro; 2005.

19. Roekmijiati. Presipitasi Bertahap Logam Berat Limbah Cair Industri Pelapisan Logam Menggunnakan Larutan Koustik Soda. Jurnal Kimia Lingkungan. Jakarta : Universitas Indonesia; 2002.

20. Salimin Z dkk. Proses Kimia Pengolahan Limbah Cair Telurium Dan Krom Dari Produksi Radioisotop 1-131. Prosiding Seminar Nasional Pengolahan Limbah, Jakarta ; Batan-ptlr; 2000.

21. Spellman dkk, Water And Wastewater Treatmen Plant Operation (Second Edition). Florida : CRC Press LLC; 2008.

22. Sugiarto,et.al. Tehnik Sampling. Jakarta:PT. Gramedia Pustaka Utama; 2003.

23. Sugiyono. Metode Penelitian Kuantitatif Kualitatif dan R \& D. Bandung: CV. Alfabeta; 2009.

24. Widowati,. Pengolahan Sumber Daya Air Terpadu. Yogyakarta : Andi press; 2008.

25. Yudo S, 2013. Pengolahan Limbah Industri Kecil Pelapisan Logam Dengan Proses Koagulasi Dan Flokulasiwww.Jurnalkeslingkupdf. Diakses tanggal 26 Juli 2018 